\title{
Multicriteria Evaluation for Protected Area Definition Aiming at Water Quality Improvement
}

\author{
Kaline de Mello ${ }^{1}$, Danilo Ribeiro da Costa ${ }^{2}$, Roberta Averna Valente ${ }^{2}$, \\ Carlos Alberto Vettorazzi ${ }^{1}$ \\ ${ }^{1}$ Escola Superior de Agricultura "Luiz de Queiroz" - ESALQ, Universidade de São Paulo - USP, Piracicaba/SP, Brasil \\ ${ }^{2}$ Universidade Federal de São Carlos - UFSCar, Sorocaba/SP, Brasil
}

\begin{abstract}
This study aimed to define potential areas for forest conservation to improve water quality, using Multicriteria Evaluation (MCE); and to verify differences between results from a multidisciplinary group of experts. We worked with the Pirapora River Watershed, Piedade/SP. The participatory method was used to identify the criteria and their relative importance. Priority maps representing expert opinion were elaborated, as well as a map with average weight values. We compared the differences between the criteria weight values and the maps of priority areas. The maps proposed distinct spatialization of priority areas, supporting the understanding of criteria that influence the decision-making process. The highest priority level was associated with areas near to springs, forest patches, and with the highest slope values. We concluded that the MCE is an efficient method to identify priority areas; however, the selection of an expert group is an essential step to generate representative analyses.
\end{abstract}

Keywords: multicriteria analysis, decision-making, watershed management. 


\section{INTRODUCTION}

Water is a natural resource, which is indispensable for life, the natural cycles of organisms, food production and economic activities. However, this resource is increasingly scarce due to the increasing demand associated with urban growth and the increase of economic activities; an increase in contaminant discharge; poor water supply infrastructure; global climate change associated with hydrological events; and water management and governance problems (Tundisi \& Barbosa, 2008). We are facing the challenge of managing immediate human needs and maintaining long-term water supply capacity, as well as being concerned about the availability of this resource with good quality (Foley et al., 2005).

According to Lima (2008), water conservation depends on the conservation of other natural resources. The terrestrial branch of the hydrological cycle is directly affected by land cover, use and catchment conditions, wherein different uses represent various degrees of risk to water resources (Seeboonruang, 2012).

The pressure on water resources generates a need for monitoring, research and implementation of management actions that provide a continuous transfer of scientific knowledge to natural resource management (Calijuri \& Bubel, 2006). Thus, area prioritization is an important step to elaborate strategies for water resource conservation, since it directs efforts and resources for conservation efforts and supports policy design regarding land use planning (Tabarelli \& Silva, 2002).

In this context, the Multicriteria Evaluation (MCE) method has been used worldwide because it consists of analyzing alternatives to solve problems using several criteria related to the study object. It allows for identifying priority alternatives for the considered object (Francisco et al., 2008). Several authors have conducted area spatialization using MCE in environmental studies seeking to prioritize important areas for natural resource conservation and landscape restoration (Valente \& Vettorazzi, 2008; Francisco et al., 2008; Silveira et al., 2014; Vettorazzi \& Valente, 2016; Saito et al., 2016).

According to Malczewski (2010) and Eastman (2011), the fundamental point of integration between MCE and Geographic Information Systems (GIS) is the combination of geographic data processing and transformations, which, when combined with user decision criteria, will result in a decision-making map. However, each case must be studied individually, considering that there are differences according to the study area and final objective.

Multicriteria decision-making involves a set of alternative area prioritization plans, which are evaluated by stakeholder groups with different interests based on multiple, conflicting and immeasurable criteria (Malczewski \& Jackson, 2000; Malczewski \& Rinner, 2015). In this way, working with different experts can result in varied proposals for a problem, even when using the same set of criteria. According to Boroushaki \& Malczewski (2010), a consensus evaluation of the proposed results is a step that must be adopted in the decision-making process.

In this context, the main objective of this study is to define potential areas for forest conservation aiming at the maintenance of water quality based on MCE in GIS environment; and to verify the differences between the results obtained by experts from several areas of knowledge regarding water resource protection.

\section{MATERIAL AND METHODS}

\subsection{Study area}

The study area is the Pirapora River watershed in the region of Piedade, São Paulo State (Figure 1). The watershed area is about 11,000 ha and located between the coordinates UTM 252987-266289 W and 7362196-7378097 S. The catchment area was defined based on "Ottobacia" data provided by the National Water Agency (ANA, 2006). The river mouth is the water collection point for the water supply of Piedade.

The region's climate is classified as Cwa (humid temperate with dry winters) (Köppen, 1948). According to Moreni \& Andrade (2002), humidity varies between 60 and $90 \%$ and temperature between 5 and $32^{\circ} \mathrm{C}$, with an annual average of $20^{\circ} \mathrm{C}$. Annual precipitation is between $1354.7 \mathrm{~mm}$ and $1807.7 \mathrm{~mm}$ (CEPAGRI, 2014). The watershed was originally covered by Atlantic Forest, which presents $25 \%$ of its original coverage (SOS Mata Atlântica, 2013).

\subsection{Multicriteria evaluation}

Priority maps for forest protection aiming at water quality improvement were generated through a Multicriteria Evaluation (MCE) approach in a GIS environment (IDRISI Kilimanjaro and ArcGIS 10.1), 


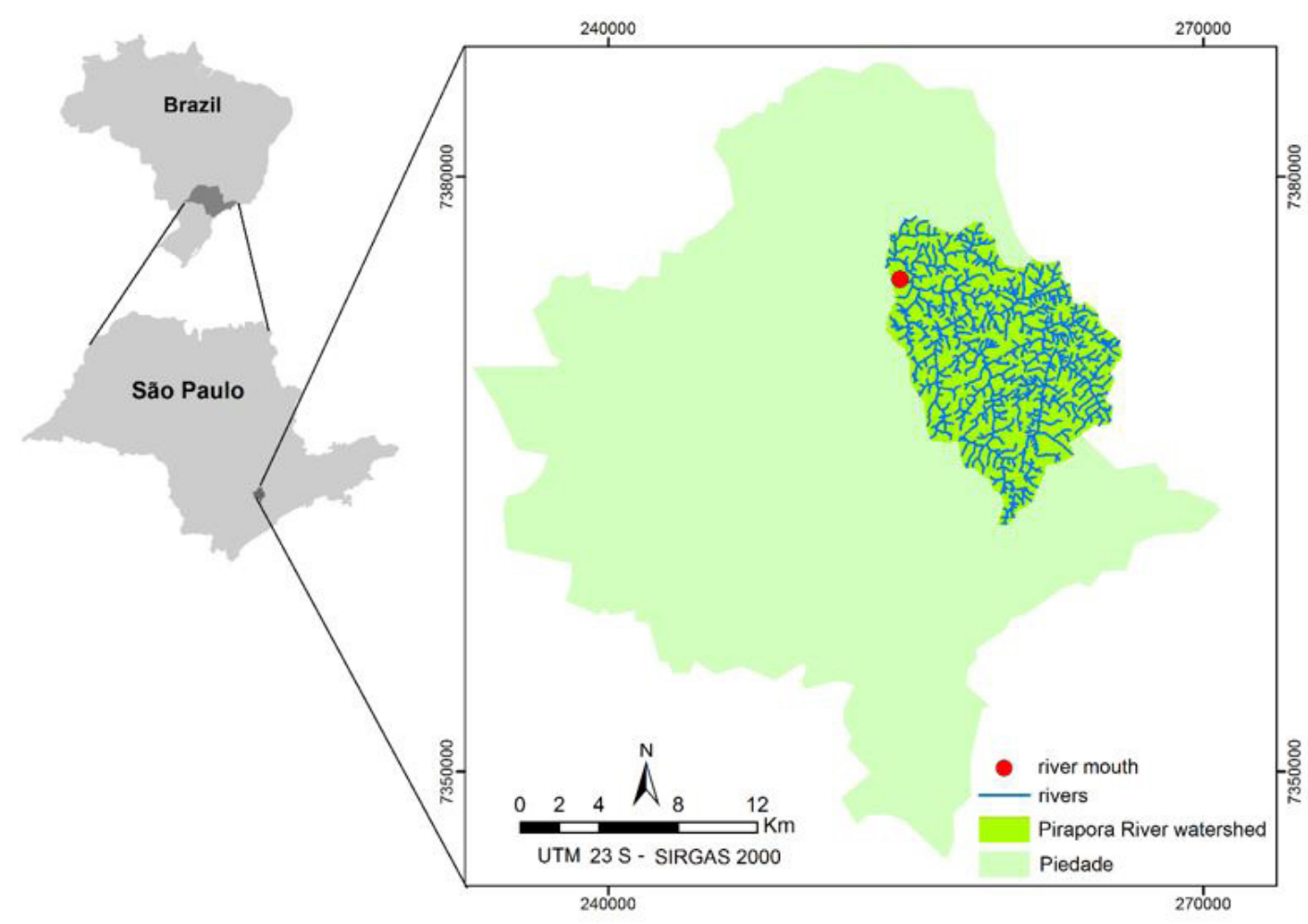

Figure 1. Location of Pirapora River watershed, Piedade, São Paulo state, Brazil.

using the Weighted Linear Combination (WLC) method. The MCE approach was selected, considering the interdisciplinarity of the decision-makers.

Criteria are the basis of MCE, and can be divided into factors and constraints (Eastman, 2011). Factors represent landscape characteristics (e.g. slope, forest remnants, roads, etc.). Constraints are related to geographical information, and restrict factors (e.g. watershed or county limits) (Valente \& Vettorazzi, 2005).

According to Valente \& Vettorazzi (2013), MCE structural process is based on three steps: (1) criteria elaboration; (2) weight definition; and (3) criteria aggregation using an MCE method.

\subsection{Criteria elaboration}

The Participatory Technique (PT) was used in the criteria definition as proposed by Eastman (2011), Boroushaki \& Malczewski (2010), and Malczewski \& Rinner (2015). According to the authors, PT is a meeting of experts who are named decision makers, who usually represent areas related to the specific study subject.

Boroushaki \& Malczewski (2010), Silveira et al. (2014), and Vettorazzi \& Valente (2016) defined criteria and weights through PT, adopting the final criteria and criteria-weight values that represented the group consensus.

In this study, the decision-makers were five experts from a University and Research Institute of São Paulo state, associated with the following areas: watershed management; Environmental Chemistry; Forest Management and Planning; Landscape Ecology; and Geology, denominated from A to E. The following factors representing the group consensus were obtained through interviews and questionnaires:

1) Distance to urban area (meters): the water quality degradation risk due to anthropic activity is greater closer to urban centers. Oliveira-Filho et al. (2012) and Ding et al. (2016) highlighted that water quality is negatively related to urbanization, i.e. 
urban land-use is related to poorer water quality of rivers (Uriarte et al., 2011; Zhou et al., 2012);

2) Proximity to forest cover (meters): streams and springs near forest cover have better water quality than areas that are distant from these patches (Pinto et al., 2012). Therefore, priority areas were associated with areas near forest remnants;

3) Slope (\%): the higher slope values are usually associated with higher values of potential sediment flow and pollutants to the rivers (Franco et al., 2012). In studying landslides, Silveira et al. (2014) defined the slope as an important factor;

4) Distance to agriculture (meters): agricultural area influences water quality through chemical element deposition and incorrect land-use management. (Deus, 2013). Besides urban areas, agriculture is also related to water degradation (Uriarte et al., 2011; Zhou et al., 2012);

5) Distance to roads (meters): roads cause forest fragmentation (Geneletti, 2004), and also their capacity to produce particulate matter.

The criteria were produced considering the following layers that make up the cartographic database of GEOPLAN laboratory/UFSCar-Sorocaba's database, produced in 2015: surface water, roads, slope, land-use/land-cover (Figure 2). The project database was standardized to the

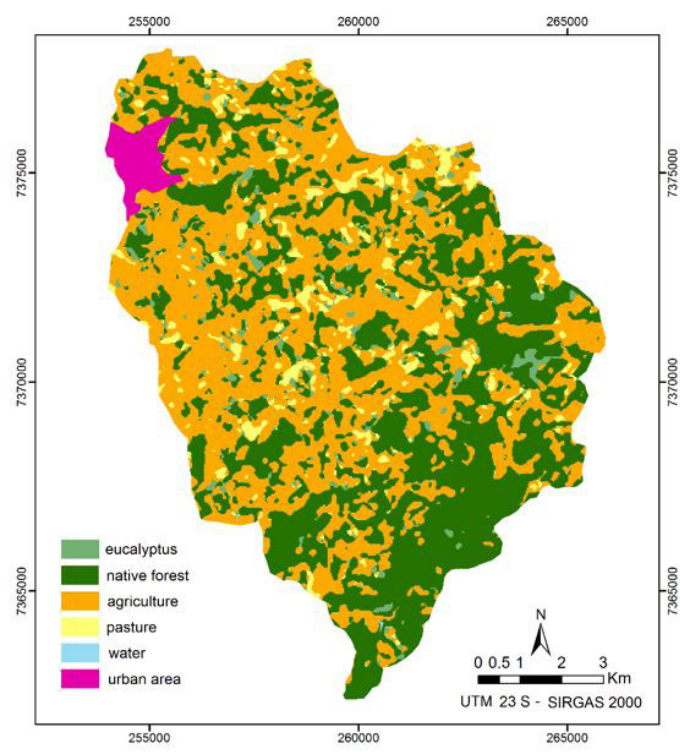

Figure 2. Land use/land cover of Pirapora River Watershed, Piedade - São Paulo state.
UTM (23S) coordinate system, SIRGAS 2000 datum, and 5-m spatial resolution.

Considering the land-use/land-cover map (Figure 2), we can say that agriculture covers $48.11 \%$ of the study area, native forest covers $41.10 \%$, eucalyptus covers $3.41 \%$, pastures cover $4.55 \%$ and urban areas cover $1.97 \%$

The criteria maps were normalized to a common scale (0-255 bytes) as required by MCE methods, while still maintaining their intrinsic characteristics.

\subsection{Factor weights}

The factor weights reflect the factors' importance for the decision-making process, and, the Participatory Technique is usually employed in their definition (Vettorazzi \& Valente, 2016). In this study, decision-makers uesd the Analytic Hierarchy Process (AHP), developed by Saaty (1980) to obtain the factor weights. In this manner, they compared criteria two by two, considering a value scale (Table 1 ) in order to fill a square matrix $n \times n$ (where $n$ is the criterions).

The Consistency Ratio (CR) (Equation 1) was calculated considering the matrix values. $\mathrm{CR}$ indicates the probability of the criterion being randomly generated and its values should be less than 0.10 . If not, the matrix should be reorganized to alter the pairwise comparison (Saaty, 1980).

$T C=\frac{C I}{R I}$

where: CI: consistency index; and RI random index.

Table 1. Pairwise comparison scale employed in the definition of criterion importance weight set according to the Analytical Hierarchy Process (AHP), for the Pirapora River Watershed (Piedade, SP).

\begin{tabular}{cl} 
Value & \multicolumn{1}{c}{$\begin{array}{c}\text { Importance level for } \\
\text { decision-making process }\end{array}$} \\
1 & $\begin{array}{l}\text { Equal - two criteria have equal importance to } \\
\text { the objective }\end{array}$ \\
3 & $\begin{array}{l}\text { Moderate - moderate importance of one } \\
\text { criterion over another }\end{array}$ \\
5 & $\begin{array}{l}\text { Strong - a criterion is significantly more } \\
\text { important than the other }\end{array}$ \\
7 & $\begin{array}{l}\text { Very strong - a criterion is very strongly favored } \\
\text { over another }\end{array}$ \\
9 & $\begin{array}{l}\text { Extremely - the importance of one criterion } \\
\text { over another is of the highest order }\end{array}$ \\
\hline
\end{tabular}

Source: Adapted from Saaty (1980) 


\subsection{Criteria aggregation}

The MCE method used in the criteria aggregation was WLC (Equation 2) through a weighted average, as mentioned by Voogd (1983).

$$
S=\sum_{j} W_{j} X_{j}
$$

where: $S$ : final value of the equation; $w_{j}$ factor weight j; $x_{j}$ : normalized value.

In this manner, the normalized criteria maps have their respective weights related to their pixel to produce the final outcome, i.e. the decision-making map.

The final equation values were reclassified into five priority levels: very low, low, medium, high and very high. Thus, we produced six priority maps for water quality improvement, highlighting that five represent the experts' (decision-makers) opinions, and the last represents the consensus (average) among their opinions.

\section{RESULTS AND DISCUSSION}

The factor weights represent the factor importance for the decision-making process and are shown in Table 2 separated by expert. According to the average value, the most important factor for the decision-making

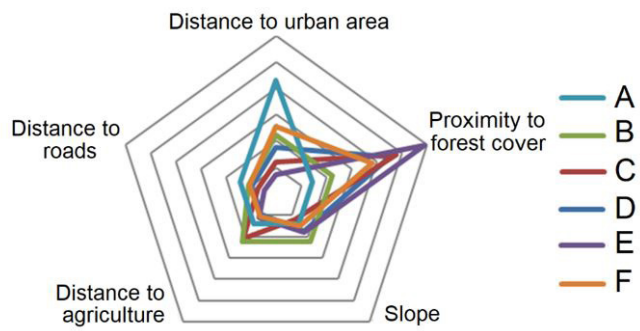

Figure 3. Researcher tendency related to the factor weight, at the Pirapora River Watershed (Piedade, SP), considering: (A-E) weights that were attributed by experts and; (F) weight average. process was proximity to forest cover, a trend followed by two experts (Figure 3). Vegetation cover promotes a reduction in soil erosion, excessive nutrient runoff, and an increase of pollutant retention and soil infiltration (Mingoti \& Vettorazzi, 2011; Tanaka et al., 2016).

The second factor that presents the highest average factor weight value (Table 2 and Figure 3) was the distance to the urban area. However, this result is related to the opinion of only one expert (A), who exclusively attributed about $43 \%$ importance to this factor. The other experts did not have the same opinion. Slope was generally the second factor with the greatest frequency of importance. Slope represents the third highest value according to the average factor weight value (Table 2 and Figure 3). Headwater areas (springs) in the basin usually located on steep slopes are more susceptible to non-point source pollution than flat areas due to errosion processes (Yang et al., 2016; Yu et al., 2016).

Similarly, for Valente \& Vettorazzi (2008) the highest-priority areas for forest conservation were found close to forest patches with the largest core area and steep areas, followed by areas distant from urban agglomerations and roads. Areas classified as high priority are those that are closest to very high priority areas (Figure 4). As mentioned by Valente \& Vettorazzi (2008), there is an expansion of areas at different priority levels, and the surrounding area is always associated with the next level of priority.

There were different proposals for priority area spatialization as a consequence of the differences between the factor's importance (Figure 4). Thus, expert selection in a study is one of the most important steps since it will directly influence the final result (Boroushaki \& Malczewski, 2010). Experts can hold differing perspectives regarding decision-making solutions, which makes it important to consult experts

Table 2. Criterion weights that were obtained by experts, for the Pirapora River Watershed (Piedade, SP).

\begin{tabular}{|c|c|c|c|c|c|c|}
\hline \multirow[b]{2}{*}{ Factors } & \multicolumn{6}{|c|}{ Factor weight by expert } \\
\hline & A & B & $\mathrm{C}$ & D & $\mathbf{E}$ & Average \\
\hline Distance to urban area & 0.429 & 0.222 & 0.120 & 0.177 & 0.071 & 0.256 \\
\hline Proximity to forest cover & 0.143 & 0.222 & 0.480 & 0.454 & 0.590 & 0.383 \\
\hline Slope & 0.143 & 0.222 & 0.120 & 0.177 & 0.179 & 0.152 \\
\hline Distance to agriculture & 0.143 & 0.222 & 0.210 & 0.096 & 0.113 & 0.105 \\
\hline Distance to roads & 0.143 & 0.111 & 0.071 & 0.096 & 0.046 & 0.105 \\
\hline
\end{tabular}



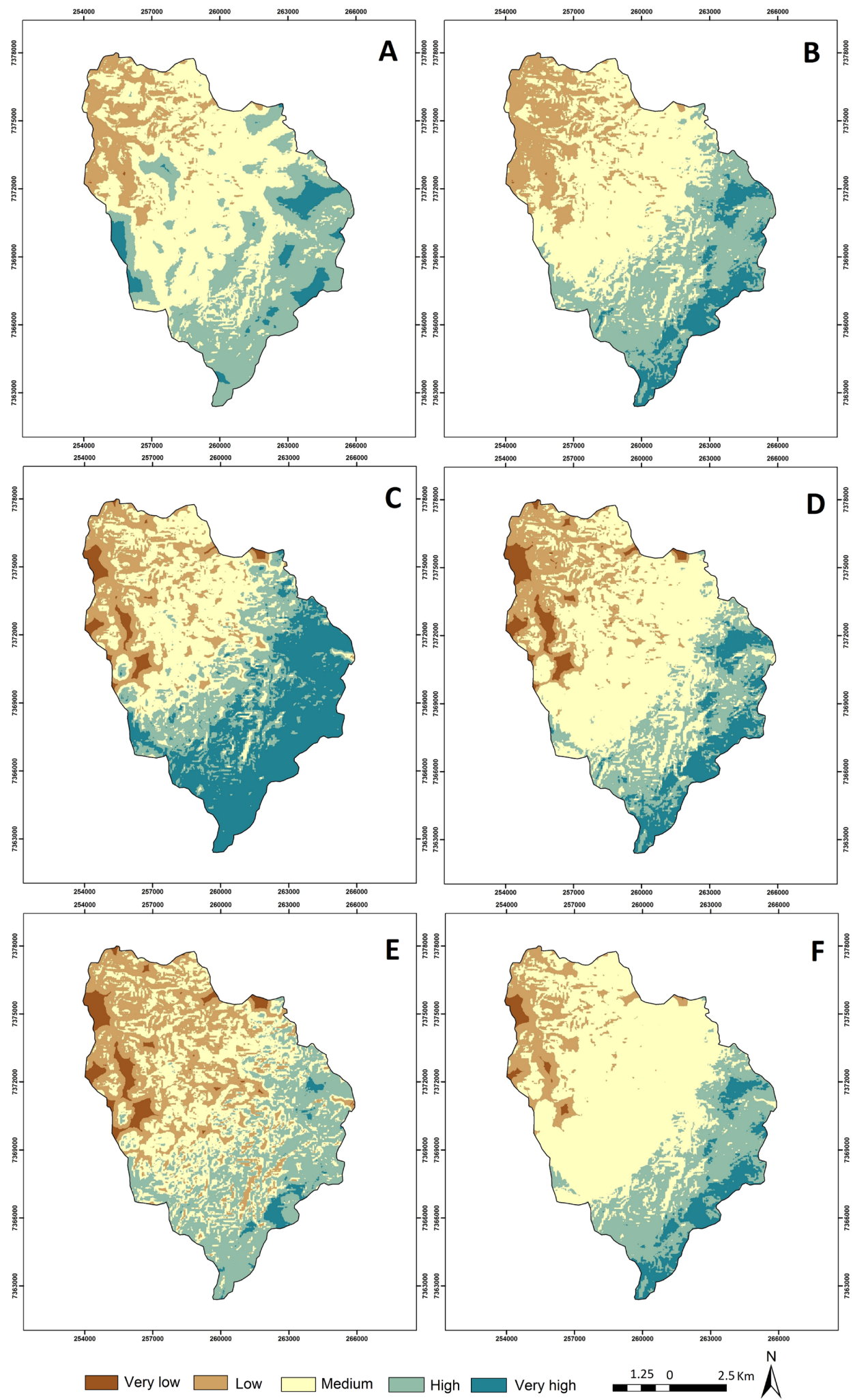

Figure 4. Priority areas for forest conservation aiming at water quality improvement at the Pirapora River Watershed (Piedade, SP) considering: (A-E) weights that were attributed by experts and; (F) weight average. 
related to the study objective or those with knowledge of the study area.

According to the map of the mean factor weight values (Figure $4 \mathrm{~F}$ ), the watershed has about $59 \%$ of its area with medium priority, $22 \%$ with high priority, $11 \%$ with low priority, and only $1 \%$ with very low priority (Table 3). However, it is necessary to better understand the behavior of the factors to understand the priority area spatialization. As mentioned by Valente \& Vettorazzi (2008), it is necessary to know the intrinsic influence of the factors. Factors have their own characteristics that influence spatialization related to how the feature is originally distributed in the landscape (Boroushaki \& Malczewski, 2010).

Only expert B attributed a different weight to the factor "distance to roads", which represents $11 \%$ of the importance for the decision-making process against $22 \%$ for the other factors (Table 2). Expert A attributed 43\% of the importance to the factor "distance to urban area," and about $14 \%$ of the importance to the other factors (Table 2). According to Valente \& Vettorazzi (2008), the attribution of equal values for the factor weights generates equalization of their relative importance, which allows us to evaluate their intrinsic influence. The set of weights proposed by expert B in this study allows this evaluation.

The map produced from the weight values proposed by expert $\mathrm{B}$ (Figure $4 \mathrm{~B}$ ) shows that $46 \%$ of the watershed has medium priority for forest conservation, $28 \%$ high priority, $17 \%$ low and $9 \%$ very high priority. Areas classified as very high priority were those that present two conditions: forest cover and highest slope values of the watershed (Figures 2 and 4B). It is important to consider that the steepest areas are located close to the watershed divide (natural limits), and decrease

Table 3. Percentage of priority level for forest conservation, considering expert opinion, for the Pirapora River Watershed (Piedade, SP).

\begin{tabular}{|lcccccc|}
$\begin{array}{c}\text { Priority } \\
\text { levels }\end{array}$ & A & B & C & D & E & Average \\
\hline Very low & 0 & 0 & 2 & 4 & 4 & 1 \\
Low & 13 & 17 & 16 & 16 & 29 & 11 \\
\hline Medium & 50 & 46 & 33 & 52 & 36 & 59 \\
High & 32 & 28 & 19 & 19 & 28 & 22 \\
\hline Very high & 5 & 9 & 30 & 10 & 2 & 7 \\
\hline Total & 100 & 100 & 100 & 100 & 100 & 100 \\
\hline
\end{tabular}

until the main river stream. The area close to the river mouth has larger forest fragments than the median portion of the watershed; however, the area does not present a steep relief and it is located near an urban area. Thus, the area was classified as low priority for forest conservation. On the other hand, the headwater areas of the watershed which are steep, presented high priority. This indicates that slope is one of the most influential factors in the decision-making process, followed by proximity to forest cover.

This fact is highlighted when we observe the map produced from the aggregation of weight values proposed by expert $A$, who attributed $43 \%$ of the importance to the factor "distance to urban area". Even in this case, slope and proximity to forest cover still have a great influence (Figure 4A and Table 2), because we have factors with equal factor weight value (0.14 - Table 2$)$.

Another point to be observed in Figure 4B is the reduced relative importance of roads, which did not promote significant changes in the decision-making process when compared with the other factors. This pattern is also observed when this factor received the same weight as other factors as proposed by expert A (Table 2 and Figure 4). We can infer that the factor "distance to roads" is among those with less influence on the decision-making process.

The priority map from the values of expert $A$ (Figure 4A) does not have areas with very low priority, and has $13 \%$ low priority, $50 \%$ medium priority, $32 \%$ high and 5\% very high priority (Table 3 ).

We highlight the contribution of the different weight attributed by expert A to "distance to urban area" (43\%) in the final map from the aggregation of the average weights of factors (Figure 4F). The most important factor (average value - Table 2) was "proximity to forest cover", followed by "distance from urban area" and slope. Thus, we observe that areas classified as a very high priority on map $\mathrm{F}$ are close to the urban center. Additionally, there is a predominance of the medium level of priority, which represents $59 \%$ of the watershed (Table 3 and Figure 4F).

The map produced from the weight values proposed by expert $\mathrm{D}$ shows a greater definition of the very high and very low priority levels than the maps from expert A and average of expert F (Figure 4). Areas classified from very high to very low priority represent $10,19,52,16$, and $4 \%$, respectively. This is due to the 
greater importance attributed to slope than in the average map $(F)$ and the map from the values of expert A (factor weight $=0.18$ - Table 2). Expert D attributed the same weight value to slope and distance to urban area. However, as the first factor is more influential, the priority levels were related to slope, especially in the presence of forest on a steep relief. In other words, when we have two conditions, the priority level is very high priority, and in the absence of the two conditions, the area was classified as very low (Figure 4D).

We can observe that Figure 4D, as with the others, shows that even when varying the factor weight value of the "distance to agriculture", its contribution to priority area spatialization is not observed, even though it represents short-cycle crops distributed throughout the study area. This pattern is also observed in the map proposed by expert $C$, who attributed a value of $21 \%$ importance to this factor, representing the second most important factor (Table 2). In addition, expert $\mathrm{C}$ attributed only $12 \%$ importance to the factor "slope," and $48 \%$ to "proximity to forest cover". Thus, this expert emphasized the importance of one of the most influential factors in the decision-making process (proximity to forest cover) and reduced the importance of the other (slope).

As a consequence, areas were prioritized due to the strong influence of the proximity to forest cover. Even in this scenario, we can observe the influence of the slope factor in the headwater areas, for example. For this reason, map C presented the higher percentage of areas (30\%) classified as very high priority among all the priority maps. The other priority levels present 2, 16, 33 and 19\% (from very low to high priority), respectively.

Expert E also attributed the greatest importance to "proximity to forest cover" (60\% importance), followed by "slope" (18\%) (Table 2, Figure 4E). The influence of the slope factor associated with proximity to forest cover generated a specification of the very high priority level. Thus, this priority level covered only $2 \%$ of the watershed, whereas the very low level represented $4 \%$, low $-29 \%$, medium - 36\%, and high - 28\%. Therefore, the influence of the factors "slope" and "proximity to forest cover" was highlighted once more, where the level of their influence is controlled by the factor weights attributed by the experts. Most of these areas are located in the headwater areas of the watershed due to the steep relief and the presence of forest remnants.
As observed by Valente \& Vettorazzi (2013), it was possible to associate areas of the watershed with very high and high priority due to the weight factors attributed by the experts (Table 2). When we have weight equalization, it is usual to find only one or two priority levels distributed in a study area.

The MCE is a flexible tool that allows the interaction between human approaches (scientific knowledge) and biophysical characteristics of the landscape in a decision-making process. However, the differences between the approaches of different experts show the importance of taking care in choosing criteria, presenting the problem to a heterogeneous group of experts in order to avoid biased results.

Collaboration of experts from different areas of knowledge related to the study objective provided different approaches to the problem and showed that the factors "proximity to forest cover", "slope", and "distance to urban area" are important factors for prioritizing areas for forest conservation with the aim of protecting water resources.

\section{CONCLUSIONS}

MCE is an efficient methodology that allows for prioritizing areas for forest conservation aiming at water quality improvement. However, it is strongly influenced by decision makers. Proximity to forest slope and distance from urban areas showed the greatest importance according to the consulted experts. Headwater areas, which are steep and present forest cover, show high and very high priority, varying their distribution according to the factor weights attributed by the experts.

The results presented indicate that we can obtain different results according to the variation of factor weight, which emphasizes the importance of defining the expert group, as well as the method to obtain the factor weights. Therefore, studies related to reducing the subjectivity of expert consultation are necessary. Adopting a multidisciplinary group is important to avoid biased analyses that generate misleading or unrepresentative data.

We highlight the importance of the previous evaluation of the factors, which influence the decision-making process, considering their spatialization and particularities in the study area. 


\section{SUBMISSION STATUS}

Received: 21 mar., 2017

Accepted: 22 june, 2017

\section{CORRESPONDENCE TO}

\section{Kaline de Mello}

Departamento de Engenharia de Biossistemas, Escola Superior de Agricultura "Luiz de Queiroz" - ESALQ, Universidade de São Paulo - USP, Avenida Pádua Dias, 11, CEP 13418-900, Piracicaba, SP, Brasil e-mail: kaline.mello@gmail.com

\section{FINANCIAL SUPPORT}

This study was supported by the São Paulo Research Foundation (FAPESP, process number 2013-03586-6).

\section{REFERENCES}

Agência Nacional de Águas - ANA. Topologia hídrica: método de construção e modelagem da base hidrográfica para suporte à gestão de recursos hídricos: versão 1.11. Brasília: ANA, Superintendência de Gestão da Informação; 2006.

Boroushaki S, Malczewski J. Measuring consensus for collaborative decision-making: a GIS-based approach. Computers, Environment and Urban Systems 2010; 34(4): 322332. http://dx.doi.org/10.1016/j.compenvurbsys.2010.02.006.

Calijuri MC, Bubel APM. Conceituação de microbacias. In: Lima WP, Zakia MJB, editors. As florestas plantadas e a água: implementando o conceito da microbacia hidrográfica como unidade de planejamento. São Carlos: RIMA; 2006.

Centro de Pesquisas Meteorológicas e Climáticas Aplicadas à Agricultura - CEPAGRI. Clima dos municípios paulistas [online]. Campinas: CEPAGRI; 2014. [cited 2015 Mar 23]. Available from: http://www.cpa.unicamp.br/outrasinformacoes/clima-dos-municipios-paulistas.html

Deus RM. Impacto ambiental na agricultura: aspectos ecológicos e necessidade de mudanças. In: Proceedings of the Integrating Cleaner Production Into Sustainability Strategies; 2013; São Paulo. São Paulo: Universidade Paulista; 2013.

Ding J, Jiang Y, Liu Q, Hou Z, Liao J, Fu L et al. Influences of the land use pattern on water quality in low-order streams of the Dongjiang River basin, China: a multi-scale analysis. The Science of the Total Environment 2016; 551-552: 205216. http://dx.doi.org/10.1016/j.scitotenv.2016.01.162. PMid:26878633.
Eastman JR. IDRISI Taiga tutoria guide do GIS and image processing. Worcester: Clark University; 2011.

Foley JA, DeFries R, Asner GP, Barford C, Bonan G, Carpenter SR et al. Global consequences of land use. Science 2005; 309(5734): 570-574. http://dx.doi.org/10.1126/ science.1111772. PMid:16040698.

Francisco CES, Coelho RM, Torres RB, Adami SF. Análise multicriterial na seleção de bacia hidrográfica para recuperação ambiental. Ciência Florestal 2008; 18(1): 1-13. http://dx.doi.org/10.5902/19805098506.

Franco GB, Betim LS, Gomes EAG, Gomes RL, Chagas CS. Relação qualidade da água e fragilidade ambiental da Bacia do Rio Almada, Bahia. Revista Brasileira de Geociencias 2012; 42: 114-127.

Geneletti D. Using spatial indicators and value functions to assess ecosystem fragmentation caused by linear infrastructures. International Journal of Applied Earth Observation and Geoinformation 2004; 5(1): 1-15. http:// dx.doi.org/10.1016/j.jag.2003.08.004.

Köppen W. Climatologia: con un estudio de los climas de la tierra. Mexico: Fondo de Cultura Econômica; 1948.

Lima WP. Hidrologia florestal aplicada ao manejo de bacias hidrográficas. 2. ed. Piracicaba: ESALQ; 2008.

Malczewski J, Jackson M. Multicriteria spatial allocation of education resources: an overview. Socio-Economic Planning Sciences 2000; 34(3): 219-235. http://dx.doi. org/10.1016/S0038-0121(99)00025-7.

Malczewski J, Rinner C. Development of GIS-MCDA. In: Malczewski J, Rinner C, editors. Multicriteria decision analysis in geographic information science. New York: Springer; 2015. p. 55-77. (vol. 1).

Malczewski J. Multiple criteria decision analysis and Geographic information Systems. In: Ehrgott M, Figueira JR, Greco S, editors. Trends in multiple criteria decision analysis. Berlin: Springer; 2010. http://dx.doi. org/10.1007/978-1-4419-5904-1_13.

Mingoti R, Vettorazzi CA. Relative reduction in annual soil loss in micro watersheds due to the relief and forest cover. Engenharia Agrícola 2011;31(6): 1202-1211. http:// dx.doi.org/10.1590/S0100-69162011000600017.

Moreni M, Andrade P. Geografia e história de Piedade. Sorocaba: Gráfica e Editora Cidade; 2002.

Oliveira-Filho PC, Haberland NT, Silva FCB, Vidal CMS, Cavallin GS. Análise da influência antrópica na qualidade da água do trecho urbano do Rio das Antas na Cidade de Irati, Paraná. Revista Tecnológica 2012; 21: 53-67.

Pinto LVA, Roma TN, Balieiro KRC. Avaliação qualitativa da água de nascentes com diferentes usos do solo em seu entorno. Cerne 2012; 18(3): 495-505. http://dx.doi. org/10.1590/S0104-77602012000300018.

Saaty T. The analytic hierarchy process. New York: McGrawHill; 1980. 
Saito NS, Moreira MA, Santos AR, Eugenio FCE, Figueiredo AC. Geotecnologia e ecologia da paisagem no monitoramento da fragmentação florestal. Floresta e Ambiente 2016; 23(2): 201-210. http://dx.doi.org/10.1590/2179-8087.119814.

Seeboonruang U. Statistical assessment of the impact of land uses on surface water quality indexes. Journal of Environmental Management 2012; 101: 134-142. http:// dx.doi.org/10.1016/j.jenvman.2011.10.019. PMid:22406854.

Silveira HLFS, Vettorazzi CA, Valente RA. Avaliação multicriterial no mapeamento da suscetibilidade de deslizamentos de terra. Revista Árvore 2014; 38(6): 973982. http://dx.doi.org/10.1590/S0100-67622014000600002.

SOS Mata Atlântica. Instituto Nacional de Pesquisas Espaciais - INPE. Atlas dos remanescentes florestais da Mata Atlântica no período 2011-2012 [online]. São Paulo: SOS Mata Atlântica; 2013. [cited 2015 Sept 25]. Available from: http://mapas.sosma.org.br/

Tabarelli M, Silva JMC. Áreas e ações prioritárias para a conservação, utilização sustentável e repartição de benefícios da biodiversidade do bioma Caatinga. In: Araújo EL, Noura AN, Sampaio EVSB, Gestinari LMS, Carneiro JMT, editors. Biodiversidade, conservação e uso sustentável da flora do Brasil. Recife: Universidade Federal de Pernambuco; 2002.

Tanaka MO, Souza ALT, Moschini LE, Oliveira AK. Influence of watershed land use and riparian characteristics on biological indicators of stream water quality in southeastern Brazil. Agriculture, Ecosystems \& Environment 2016; 216 : 333-339. http://dx.doi.org/10.1016/j.agee.2015.10.016.

Tundisi JG, Barbosa FAR. Conservação e uso sustentável de recursos hídricos. In: Barbosa FA. Ângulos da água: desafios da integração. Belo Horizonte: Editora UFMG; 2008.

Uriarte M, Yackulic CB, Lim Y, Arce-Nazario JA. Influence of land use on water quality in a tropical landscape: a multi-scale analysis. Landscape Ecology 2011; 26(8): 1151-1164. http://dx.doi.org/10.1007/s10980-011-9642-y. PMid:26146455.
Valente ROA, Vettorazzi CA. Comparação entre métodos de avaliação multicriterial, em ambiente SIG, para a conservação e a preservação florestal. Scientia Forestalis 2005; 69(69): 51-61.

Valente ROA, Vettorazzi CA. Definition of priority areas for forest conservation through the ordered weighted averaging method. Forest Ecology and Management 2008; 256(6): 1408-1417. http://dx.doi.org/10.1016/j. foreco.2008.07.006.

Valente ROA, Vettorazzi CA. Avaliação multicriterial na definição de áreas prioritárias à restauração florestal, visando ao manejo sustentável da água. In: Argemiro LB, Carolina B, Jeferson F, Selbach OH, editors. Sustentabilidade do uso da água nos trópicos e subtrópicos: estudos de caso. Ijuí: Unijui; 2013.

Vettorazzi CA, Valente RA. Priority areas for forest restoration aiming at the conservation of water resources. Ecological Engineering 2016; 94: 255-267. http://dx.doi. org/10.1016/j.ecoleng.2016.05.069.

Voogd H. Multi-criteria evaluation for urban and regional planning. London: Pion; 1983.

Yang H, Wang G, Wang L, Zheng B. Impact of land use changes on water quality in headwater of the Three Gorges Reservoir. Environmental Science and Pollution Research International 2016; 23(12): 11448-11460. http:// dx.doi.org/10.1007/s11356-015-5922-4. PMid:26686517.

Yu S, Xu Z, Wu W, Zuo D. Effect of land use types on stream water quality under seasonal variation and topographic characteristics in the Wei River basin, China. Ecological Indicators 2016; 60: 202-212. http://dx.doi.org/10.1016/j. ecolind.2015.06.029.

Zhou T, Wu J, Peng S. Assessing the effects of landscape pattern on river water quality at multiple scales: a case study of the Dongjiang River watershed, China. Ecological Indicators 2012; 23: 166-175. http://dx.doi.org/10.1016/j. ecolind.2012.03.013. 